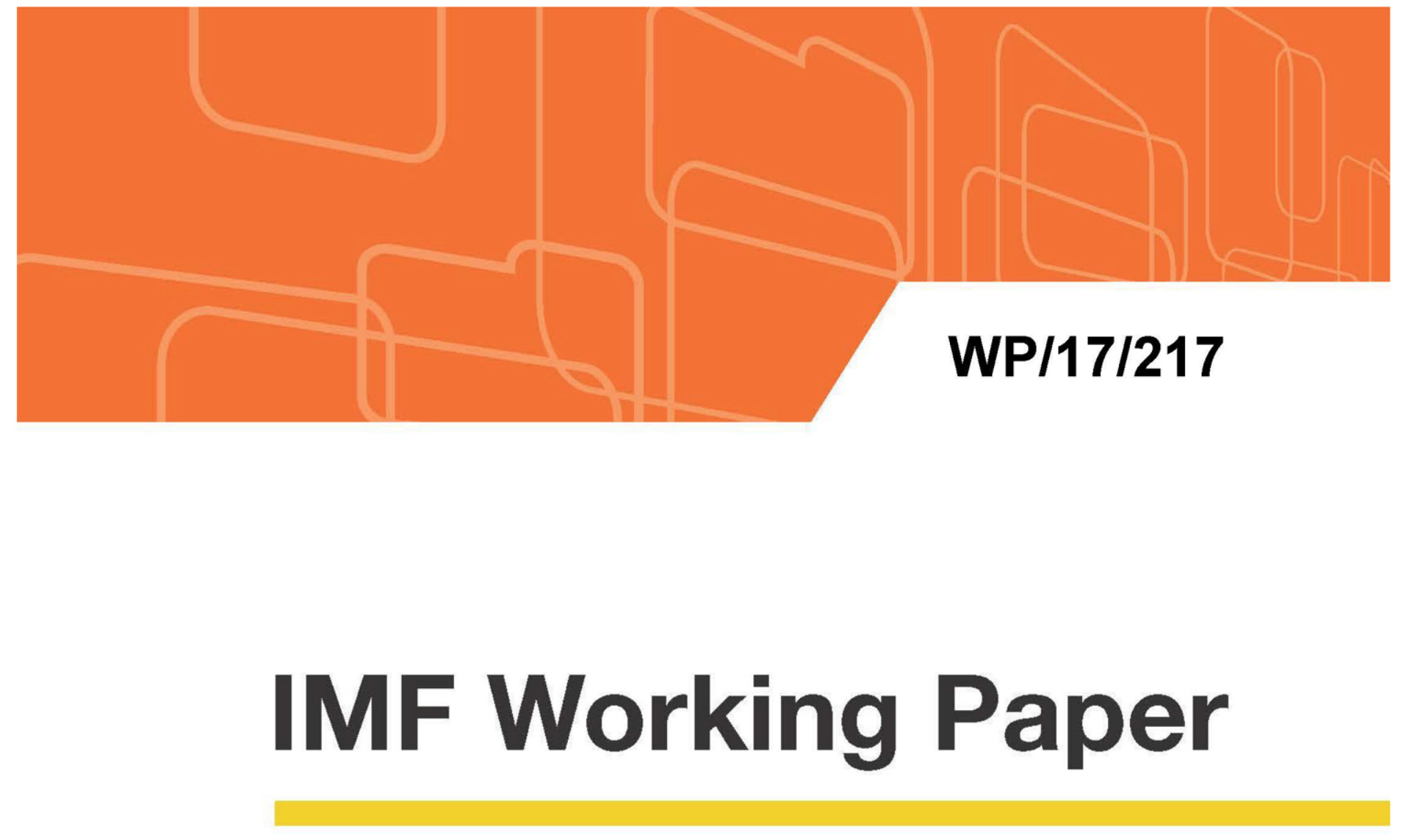

\title{
The Macroeconomic (and Distributional) Effects of Public Investment in Developing Economies
}

by Davide Furceri and Bin Grace Li

IMF Working Papers describe research in progress by the author(s) and are published to elicit comments and to encourage debate. The views expressed in IMF Working Papers are those of the author(s) and do not necessarily represent the views of the IMF, its Executive Board, or IMF management.

$$
\text { I N T E R N A T I O N A L M O N E T A R Y F U N D }
$$




\section{WP/17/217}

\section{IMF Working Paper}

\section{The Macroeconomic (and Distributional) Effects of Public Investment in Developing Economies}

by Davide Furceri and Bin Grace Li

IMF Working Papers describe research in progress by the author(s) and are published to elicit comments and to encourage debate. The views expressed in IMF Working Papers are those of the author(s) and do not necessarily represent the views of the IMF, its Executive Board, or IMF management.

$$
\text { I N T E R N A T I O N A L M O N E T A R Y F U N D }
$$




\title{
IMF Working Paper
}

Research Department

\section{The Macroeconomic (and Distributional) Effects of Public Investment in Developing Economies}

\section{Prepared by Davide Furceri and Bin Grace Li ${ }^{1}$}

Authorized for distribution by Chris Papageorgiou

October 2017

\section{IMF Working Papers describe research in progress by the author(s) and are published to elicit comments and to encourage debate. The views expressed in IMF Working Papers are those of the author(s) and do not necessarily represent the views of the IMF, its Executive Board, or IMF management.}

\begin{abstract}
This paper provides new empirical evidence of the macroeconomic effects of public investment in developing economies. Using public investment forecast errors to identify unanticipated changes in public investment, the paper finds that increased public investment raises output in the short and medium term, with an average short-term fiscal multiplier of about 0.2. We find some evidence that the effects are larger: (i) during periods of slack; (ii) in economies operating with fixed exchange rate regimes; (iii) in more closed economies; (iv) in countries with lower public debt; and (v) in countries with higher investment efficiency. Finally, we show that increases in public investment tend to lower income inequality.

JEL Classification Numbers: E32, D84, F02, Q41, Q43, Q48.

Keywords: Public investment, Fiscal policy, Growth, Inequality.

Authors' E-Mail Addresses: dfurceri@,imf.org, bli2@,imf.org
\end{abstract}

\footnotetext{
${ }^{1}$ We are grateful to Ali Abbas, Francisco Arizala, Matthieu Bellon, Douglas Gollin, Jesus Gonzalez-Garcia, Prakash Loungani, Samah Mazraani, Chris Papageorgiou, Tim Willems and seminar participants at the IMF Development Economics Seminar and at the "CSAE Conference 2017: Economic Development in Africa" for comments and suggestions. This working paper is part of a research project on macroeconomic policy in lowincome countries supported by U.K.'s Department for International Development. We are also grateful to Karina Chavez for excellent editorial assistance. The views expressed in this Working Paper are those of the author(s) and do not necessarily represent those of the IMF, IMF policy, or of DFID.
} 
Contents

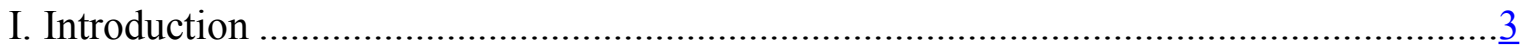

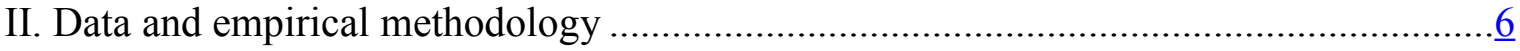

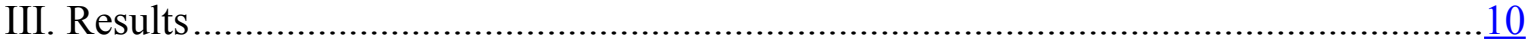

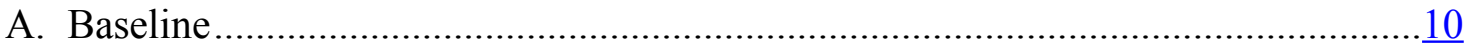

B. Effects across episodes- and country-specific characteristics …………………....13

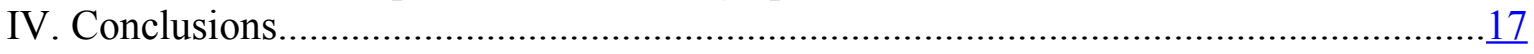

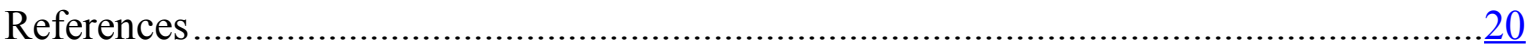

\section{List of Figures}

Figure 1: The effect of public investment shocks on output............................................23

Figure 2: The effect of public investment shocks on employment ....................................24

Figure 3: The effect of public investment shocks on private investment ............................24

Figure 4: The effect of public investment shocks - robustness checks I...........................25

Figure 5: The effect of public investment shocks - emerging markets vs. low-income

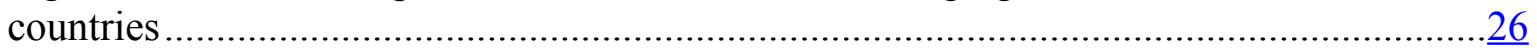

Figure 6: The effect of public investment shocks - controlling for influential observations

Figure 7: The effect of public investment shocks - the role of business cycle ………......28

Figure 8: The effect of public investment shocks - the role of exchange rate regime .........29

Figure 9: The effect of public investment shocks - the role of trade openness .................... $\underline{30}$

Figure 10: The effect of public investment shocks - the role of public debt.........................31

Figure 11: The effect of public investment shocks - the role of investment efficiency ........32

Figure 12: The effect of public consumption shocks on output...........................................33

Figure 13: The effect of public investment shocks on inequality .........................................33

\section{List of Tables}

Table 1: The effect of public investment shocks on output ................................................34

\section{Appendix}

Figure A1: Public investment shocks …………………..........................................

Table A1: List of countries in the sample ....................................................................37

Table A2: List of countries and the sample periods .......................................................... 


\section{INTRODUCTION}

Public investment is considered as one of the key policy levers to foster economic prospects in developing economies (World Economic Forum, 2010). Given the importance of public investment as a potential engine of growth, it is not surprising that a vast economic literature has tried to assess its macroeconomic effects. ${ }^{2}$ However, despite these efforts, there is still significant uncertainty regarding the magnitude of the effect of public investment on output. This is particularly the case for developing economies, where data availability (and quality) is more scarce.

One of the key sources of this uncertainty is due to the difficulty of identifying changes in public investment that are likely to be uncorrelated with contemporaneous macroeconomic shocks, and that therefore can be deemed as exogenous. Four main approaches have been proposed in the literature to identify exogenous fiscal shocks. The first is the "natural experiment" approach proposed by Barro (1981) and further developed by Ramey in subsequent papers (Ramey and Shapiro 1998; Ramey 2011a; Ramey 2011b; Ramey and Zubairy forthcoming). This approach uses fluctuations in military spending to identify government spending shocks. The second is the structural vector auto regressions (SVARs) approach developed by Blanchard and Perotti (2002), and applied to developing economies by Ilzetzki and others, 2013), where exogenous fiscal shocks are identified under the assumption that government spending is unlikely to respond to macroeconomic shocks

\footnotetext{
2 Barro (1990), Barro and Sala-i-Martin (1992), Futagami and others (1993) and Glomm and Ravikumar (1994) analyze the growth impact of public investment in the context of endogenous growth models. More recently, Chatterjee and Turnovsky (2007), Agenor (2010), Buffie and others (2012), Portillo and others (2010, 2012) explore the importance of some developing countries' features to shape the growth effect public investment in the economies. Several studies have also assessed the macroeconomic effects of aid-financed public investment expansions (e.g., Adam and Bevan, 2006; Cerra and others 2008; and Berg and others 2010).
} 
within the same quarter. The third identification strategy is the one proposed by Kraay (2012) and Kraay (2014) for developing countries, which uses loans from official creditors—such as the World Bank and other multilateral and bilateral aid agencies—as exogenous sources of fluctuations in government spending. The fourth approach is the one proposed by Auerbach and Gorodnichenko (2012b, 2013), and applied by Abiad and others (2016) to examine the effect of public investment in advanced economies, which identifies government spending shocks as the forecast errors in government spending.

In this paper, we employ the approach pioneered by Auerbach and Gorodnichenko (AG) for two reasons. The first is that data limitation precludes the natural experiment and the SVAR approaches for a large set of emerging and developing economies. ${ }^{3}$ The second reason is that this approach overcomes the problem of "fiscal foresight" (see Forni and Gambetti 2010; Leeper, Richter, and Walker 2012; Leeper, Walker, and Yang 2013; and Ben Zeev and Pappa 2014). Agents receiving news about changes in government spending in advance may alter their consumption and investment decisions well before the changes occur. An econometrician who uses just the information contained in the change in actual spending would be relying on an information set that is smaller than that used by economic agents, which could lead to biased estimates. By using forecast errors, the AG methodology effectively aligns the economic agents' and the econometrician's information sets. In addition, as stressed by Ramey (2011b), it is likely that private agents respond to unanticipated changes of spending, rather than to actual changes in spending. Therefore, the

\footnotetext{
${ }^{3}$ Ilzetzki and others (2013) assembled quarterly data on government spending for 24 emerging market economies. In contrast, the methodology chosen in the paper allows to cover an unbalanced sample of 79 emerging market and developing economies (see Table A1 in Appendix for the list of countries).
} 
approach used in the paper provides a better identification of the response of output to increases in public spending.

Once public investment shocks are identified, we use the local projections approach of Jordà (2005) to trace out the short- and medium-run output responses for a panel of 79 emerging markets and low-income countries over the period 1990-2013. We then examine the role of several country- and episode-specific characteristics that can potentially shape these responses.

The paper's main results can be summarized as follows: Public investment increases, on average, output both in the short and medium term. In particular, our estimates suggest a short-term fiscal multiplier of about 0.2 for developing economies, broadly in line with previous estimates found in the literature (e.g. Kraay 2012; Ilzetzki and others 2013). The average effects, however, mask difference across episodes and countries. In particular, consistent with previous studies, we find tentative evidence suggesting that the effects are larger: (i) during periods of slack; (ii) in economies operating with fixed exchange rate regimes; (iii) in more closed economies; (iv) in countries with lower public debt; and (v) in countries with higher investment efficiency. ${ }^{4}$ Finally, we show that increases in public investment tend to lower income inequality—proxied by the Gini coefficient of market income.

The paper contributes to three strands of the literature. The first strand is on the role of infrastructure and public investment in economic development. A large body of literature

\footnotetext{
${ }^{4}$ For example, Ilzetzki and others (2013) finds larger fiscal multipliers countries with fixed exchange rate regimes, lower trade openness, and lower debt levels. Similarly, Corsetti and others (2012) and Nakamura and Steinsson (2011) find that countries with fixed exchange rates have larger multipliers.
} 
has focused on the optimal scale of public investment by estimating the long-term elasticity of output to public infrastructure capital using a production function approach (see Romp and de Haan 2007; Straub 2011; and Bom and Ligthart 2014, for surveys of the literature). With this approach, however, it is difficult to obtain estimates that could be given a causal interpretation. Unobservable factors may affect both economic performance and government investment decisions, and the relationship between the two likely runs in both directions. In contrast, our empirical approach mitigates this concern. The second strand of the literature is on the role the business cycle and country-specific factors in shaping the response of output to fiscal shocks (see, among others, Blanchard and Perotti 2002; Favero and Giavazzi 2009; Romer and Romer 2010; Kraay 2012; Auerbach and Gorodnichenko 2013a, 2013b; and Blanchard and Leigh 2013; Ilzetzki and others 2013; Ramey and Zubairy forthcoming). The third strand of the literature is on the relation between fiscal policy and inequality. An extended literature has examined the effect of tax and transfers (IMF 2014) and fiscal consolidations episodes (Ball and others, 2013) on inequality. The paper complements this literature by looking at the distributional effects of public investment.

The rest of the paper is organized as follows. Section II presents the empirical analysis used to assess the macroeconomic effect of public investment and describes the data. Section III presents the main findings and several robustness checks of the empirical results. Section IV concludes by summarizing the main findings and policy implications.

\section{Data AND EMPIRICAl Methodology}

This section explains the empirical methodology used in the analysis. Following the statistical approach proposed by Auerbach and Gorodnichenko (2013a, 2013b) and Abiad and others (2016), we estimate the causal effect of public investment on output by identifying 
unanticipated changes in public investment. Using forecasts from IMF World Economic Outlook publications, we construct public investment shocks $(F E)$ as the difference between the growth rate of actual real public investment $(\Delta \ln P I)$ and the rate which is forecast by analysts as of October of the same year $\left(\Delta \ln P I^{E}\right)$ :

$$
F E_{i, t}=\Delta \ln P I_{i, t}-\Delta \ln P I_{i, t}^{E}=\left(\ln P I_{i, t}-\ln P I_{i, t-1}\right)-\left(\ln P I_{i, t}^{E}-\ln P I_{i, t-1}\right)
$$

As previously discussed, this methodology overcomes the problem of "fiscal foresight" (see Forni and Gambetti 2010; Leeper, Richter, and Walker 2012; Leeper, Walker, and Yang 2013; and Ben Zeev and Pappa 2014). Agents receive news about changes in fiscal spending in advance and they may alter their consumption and investment behavior well before the changes occur. An econometrician who uses just the information contained in the change in actual public investment would be relying on an information set that is smaller than that used by economic agents, which could lead to inconsistent estimates of the effects of public investment. By using forecast errors, the AG methodology effectively aligns the economic agents' and the econometrician's information sets.

We use the forecast of public investment made in October of the same year to minimizes the likelihood that unanticipated changes in public investment capture the potentially endogenous response of fiscal policy to the state of the economy. Even if public investment shocks are unanticipated, they may still be responding to unanticipated business cycle conditions: for example, public projects may be stepped up if growth turns out to be unexpectedly weak, or alternatively, they may be postponed if fiscal space is tight and revenues surprise on the downside. For this to be a concern, however, such adjustments to public investment need to happen within the same quarter news about the state of the 
economy is received (i.e. between October and December), since all information about both public investment and economic performance up until October are incorporated in the October forecasts. This is highly unlikely as discussed by Blanchard and Perotti (2002). Furthermore, we later demonstrate that our findings are robust when controlling for growth news.

Figure A1 in the appendix provides a distribution of these shocks. The magnitude of the shocks ranges between -195 and 185 percent, with the vast majority of the shocks (90 percent) being between -45 and 43 percent, and the average (median) shock of about -1.8 (1.7) percent. ${ }^{5}$ As a robustness check, we show later that the results are not driven by few influential observations.

Using these measures of unanticipated public investment shocks, we estimate two econometric specifications. The first estimates the average impact of public investment shocks on real GDP. The second examines whether the effects of public investment vary with episode- and country-specifics characteristics such as the role of the business cycle, the exchange rate regime, trade openness, the initial debt-to-GDP ratio, the degree of investment efficiency.

We use the local projection method (Jordà, 2005) to estimate impulse-response functions. This approach has been advocated by Stock and Watson (2007) and Auerbach and Gorodichencko (2013a), among others, as a flexible alternative that does not impose the dynamic restrictions embedded in vector autoregression (autoregressive-distributed lag)

\footnotetext{
${ }^{5}$ The actual growth rate of public investment ranges from -186 to 7586 in the full sample. Table A1 and A2 in the Appendix report the list of countries and period of time for which data on public investment shocks are available.
} 
specifications and is particularly suited to estimating nonlinearities in the dynamic response.

The first regression specification is estimated as follows:

$y_{i, t+k}-y_{i, t-1}=\alpha_{i}^{k}+\vartheta_{t}^{k}+\beta^{k} F E_{i, t}+\theta^{k} X_{i, t}+\varepsilon_{i, t}^{k}$

in which $y$ is the logarithm of output; $\alpha_{i}$ are country fixed effects, included to control for all time-invariant differences across countries (such as in countries' trend growth rates); $\vartheta_{t}$ are time fixed effects, included to control for global shocks such as shifts in oil prices or the global business cycle; $F E_{i, t}$ is the public investment shocks; and $X_{i t}$ is a set a of control variables including two lags of public investment shocks, as well as two lags of GDP growth. ${ }^{6}$

Equation (2) is estimated for each period (year) $k=0, \ldots, 5$, where $k=0$ is the year of the public investment shock. Impulse-response functions are computed using the estimated coefficients $\beta^{k}$, while the confidence bands associated with the estimated impulse-response functions are obtained using the estimated standard errors of the coefficients $\beta^{k}$, based on clustered robust standard errors at the country level.

In the second specification, the response of the variable of interest is allowed to vary with the business cycle and country-specific characteristics. The second regression specification is estimated as follows:

$y_{i, t+k}-y_{i, t-1}=\alpha_{i}^{k}+\vartheta_{t}^{k}+\beta_{1}^{k} G\left(z_{i t}\right) F E_{i, t}+\beta_{2}^{k}\left(1-G\left(z_{i t}\right)\right) F E_{i, t}+\theta^{k} M_{i, t}+\varepsilon_{i, t}^{k}$,

\footnotetext{
${ }^{6}$ While the Nickel-bias may be a problem, given the limited time dimension of out panel $(\mathrm{T}=24)$, similar results - available upon request - are obtained when dropping lags of the dependent variable and when estimating equation (2) using GMM.
} 
with

$G\left(z_{i t}\right)=\frac{\exp \left(-\gamma z_{i t}\right)}{1+\exp \left(-\gamma z_{i t}\right)}, \quad \gamma>0$,

in which $z$ is an indicator of the business cycle (or country-specific characteristic),

normalized to have zero mean and unit variance; $\mathrm{G}\left(\mathrm{z}_{\mathrm{i}}\right)$ is the corresponding smooth transition function; and $M_{i t}$ is the same set of control variables used in the baseline specification but now also including $\mathrm{G}\left(\mathrm{z}_{i t}\right)$. We use real GDP growth as a measure of the business cycle. We use the Public Investment Management Index (PIMI), constructed by Dabla-Norris et al. (2012), as a measure of investment efficiency. As in Abiad and et al (2016), we set the parameter $\gamma=1.5$. The results do not qualitatively change if we use alternative values of $\gamma$.

As discussed in Auerbach and Gorodnichenko (2012b, 2013), the local projection approach to estimating non-linear effects is equivalent to the smooth transition autoregressive (STAR) model developed by Granger and Teravistra (1993). The main advantage of this approach relative to estimating STVARs for each regime is that it uses a larger number of observations to compute the impulse response functions of only the dependent variables of interest, improving the stability and precision of the estimates. This estimation strategy can also more easily handle the potential correlation of the standard errors within countries, by clustering at the country level.

\section{RESUlts}

\section{A. Baseline}

The results obtained by estimating equation (2) show that public investment shocks have statistically significant effects on output (Figure 1, Panel A). An unanticipated 10 percent increase in government investment spending increases the level of output by about 
0.1 percent in the same year. Using the sample average of government investment as a percentage of output (about 5 percent of GDP), this implies a short-term (public investment spending) fiscal multiplier of about 0.2 . This estimates is broadly in line with previous results in the literature. For example, Kraay (2014) finds an average fiscal multiplier ranging between 0.2 and 0.4 for a sample of 109 developing economies. For a panel of 24 emerging market economies, Ilzetzki and others (2013) find a fiscal multiplier between 0 and 0.6.

The effect of public investment on output increases over time. In particular, we find that five years after an unanticipated shock to government investment spending of 10 percent, the level of real output is about 0.4 percent higher.

These output effects are smaller than those found for advanced economies using the same empirical approach. In particular, Abiad and others (2016) find that the short-term multiplier associated with public investment shock is about 0.5 . While different factors may explain these smaller effects in developing economies than in advanced ones, a prominent explanation that has been put forward in the literature (e.g. Pritchett 2000) is the lower investment process efficiency - a factor which we empirically examine in the next section.

The results also suggest that a 10 percent public investment shock increases employment of about 0.15 percent in the short term (Figure 2). Finally, we find evidence that public investment shocks, on average, tend to crowd-in private investment (Figure 3).

\section{Robustness checks}

Before proceeding to examine some of the episodes- and country-specific factors shaping the response of output to public investment shocks, we present several robustness checks to validate the average estimated effects. 
A possible concern with the identification of public investment shocks is that they may be endogenous to output growth surprises. While the use of the forecasts made in October of the same year mitigates this concern, we check the robustness of our results by adding as control variables current and lagged output growth innovations - defined as the difference between actual GDP growth and the rate forecast by analyst in October of the same year. The results are very close to those obtained in the baseline (Figure 4, Panel A). ${ }^{7}$

Another possible problem in identifying exogenous public investment shocks is that the forecast errors for public investment are correlated with those of other budget components. To address this concern, we add as control variables the current and lagged forecast errors of the budget balance. The results, presented in Panel B of Figure 4, show that the response function of output is almost identical and not statistically significantly different from the baseline.

Our findings are also robust to alternative measures of public investment shocks, estimation periods, and country samples. As a first robustness check, we use the forecasts of the October issue of the previous year (instead of the forecast from October of the same year) to compute government investment forecast errors. The results in Panel C of Figure 4 show that the response function of real output is very close and not statistically significantly different from that reported in the baseline. ${ }^{8}$ As an additional robustness check, we assess whether the effects of public investment on output have changed over time. The results show

\footnotetext{
${ }^{7}$ The correlation between public investment shocks and growth forecast errors is -0.01 , confirming that public investment shocks could be deemed exogenous to growth surprises. Similar results are obtained when we regress public investment forecast errors on growth forecast errors and use the residuals from this regression as our measure of public investment shocks.

${ }^{8}$ Similar results are obtained using the forecasts of the April issue of the same year.
} 
that this is not the case (Figure 4, Panel D). In addition, the results obtained by estimating equation (2) separately for emerging markets and low-income countries suggest that the response of output does not statistically significantly differ between the two groups (Figure 5) - even though the effects are smaller and less precisely estimated for low-income countries.

A concern regarding the construction of public investment shocks is that the results may be driven by few influential observations. As previously discussed, a potently important difficulty in obtaining precise estimates for developing countries is due to the measurement error associated with the fiscal shocks. To check the sensitivity of our results to outliers, we re-estimated equation (2) by randomly dropping 10 (and 25) percent of countries in our sample at a time. We repeat this exercise 100 times. The results reported in Figure 6 show the average of all the point estimates across our 100 bootstraps, as well as the 90 percent confidence bands in the bootstraps. The average estimates of the repeated bootstraps are very close to and not statistically different from the baseline, suggesting that dropping individual countries has relatively little impact on the results (Figure 6).

\section{B. Effects across episodes- and country-specific characteristics}

\section{Role of the business cycle}

Several studies in the literature have shown that the response of output to government spending shocks tends to be higher during periods of recessions than in expansions (see, among others, Auerbach and Gorodnichenko 2012b; and Blanchard and Leigh 2013; Ramey and Zubairy forthcoming). The results obtained estimating equation (3) seem to corroborate this finding (Figure 7). At the same time, the difference in the point estimates are small 
relative to the estimated standard errors and are in most of the cases not statistically significant. ${ }^{9}$

\section{Exchange rate regime}

A potential source of heterogeneity in the response across countries (and times) is the exchange rate regimes. According to the standard open-economy IS/LM framework (the Mundell-Fleming model) with limited capital mobility, fiscal shocks have larger effects in economies operating under fixed exchange rate regimes. To test for this prediction, we reestimated equation (3) using the exchange rate regime classification by Ilzetzki and others (2008). The results reported in Figure 8 confirm that the macroeconomic effects of public investment shocks are substantially stronger in countries with fixed exchange rate regimes: the increase in GDP is positive in countries with fixed exchange rate regimes, but negative (and insignificant) in countries with flexible exchange rate regimes. However, given the relatively large standard errors, the difference in the output response is statistically significant only for $k=0$ and $k=4$.

\section{Openness to trade}

Another source of heterogeneity is related to trade openness. According to theory, the macroeconomic effect of fiscal shocks is lower in countries where the marginal propensity to import is higher. This is because part of the effect of public investment on output are leaked through imports. To test this possibility, we re-estimated equation (3) using trade opennessdefined as the share of imports and exports in GDP, taken from the IMF WEO. Similar to the finding of Ilzetzki and others (2013), the results reported in Figure 9 show that while the

\footnotetext{
${ }^{9}$ The difference is statistically significant only 4 years after the public investment shock.
} 
output response is positive in countries with very low trade openness, the response is negative (and insignificant) in countries with very high trade openness. At the same time, the differences in the point estimates are small relative to the estimated standard errors and are in most of the cases not statistically significant.

\section{Debt-to-GDP}

A potential source of heterogeneity is the debt-to-GDP ratio. In countries, where the debt-to-GDP is high, an increase in public investment may increase pressures on public debt sustainability and raise interest rates, therefore mitigating the impact of public investment on output. To examine this possibility, we re-estimated equation (3) using the debt to-GDP-ratio (taken from the IMF WEO dataset). The results suggest that the effect of public investment shocks significantly vary with the initial public debt positions: in countries with very low debt the response of output is positive, significant and higher than the baseline, but in countries with very high debt the response is negative and not statistically significant (Figure 10). The difference in the impulse response functions is statistically significant at each horizon $k$. This result is consistent with Corsetti and others (2012) and Huidrom and others (2016), who find that fiscal multipliers are smaller in countries with worse initial fiscal positions.

\section{Investment efficiency}

Inefficiencies in the public investment process, such as poor project selection, implementation, and monitoring, can result in only a fraction of public investment translating into productive infrastructure, limiting the long-term output gains (Pritchett 2000; Caselli 2005). In addition, public investment efficiency may also affect short-term multipliers to the extent that investment spending is diverted (e.g., into the pockets of corrupt officials) and not 
spent, or is used for consumption which has a lower multiplier than investment — as we will show next.

To examine this possibility, we re-estimated equation (3) using the PIMI indicator of investment efficiency. The index captures the institutional environment underpinning public investment management across four different stages: project appraisal, selection, implementation, and evaluation.

The results suggest that the response of the level of output to public investment shocks is significantly stronger in countries with higher public investment efficiency, both in the short and in the medium term (Figure 11). ${ }^{10}$ Again, while the differences in the response are economically significant, they are relatively small compared to the estimated standard errors. As a result, the difference is not statistically significant.

\section{Public investment versus government consumption}

While the focus of the paper is on public investment, it is interesting to see what is the effect of public consumption on output. In developing countries, the composition of government purchases is usually an important factor to determine the impact of government spending on output. To explore this question, we re-estimated equation (1) using the forecast errors of public consumption expenditure. The results suggest that the effect of public consumption on output is only significant in the short run - that is, at the time of the shock (Figure 12). The results also suggest that the short-term fiscal multiplier (computed as the ratio of the estimated coefficient to the public consumption-output share) is about 0.1 , slightly smaller than the one associated with public investment $(0.2)$. The result that public

\footnotetext{
${ }^{10}$ Consistent with Berg and others (2015), the results also suggest that public investment efficiency does not significantly influence the effect of public investment on medium-term growth.
} 
investment has a larger fiscal multiplier than government consumption is also consistent with Ilzetzki and others (2013).

\section{Distributional effects of public investment}

Another interesting question is whether public investment ameliorates or deteriorates income inequality. From a theoretical point of view, the effect of public investment on inequality is uncertain and depends on: (i) whether infrastructure investment lead to productivity gains only in the sector involved or whether gains are diffused across all sectors; (ii) if the workers in the sector which mostly benefits from infrastructure investment have higher initial wages than workers in other sectors.

To examine the distributional effect of public investment, we re-estimate equation (1) using the Gini coefficient of market income instead of output as the dependent variable. ${ }^{11}$ The results in Figure 13 suggest that increases in public investment tend to reduce inequality in the short and medium term. In particular, a 10 percent increase in public investment is associated with a reduction in the Gini coefficient of about 0.2 percent - that is, approximately $3 / 4$ of the standard deviation of the average annual change in the Gini coefficient in the sample.

\section{Conclusions}

Public investment in infrastructure - transportation, electricity, telecommunication and so forth - is typically recognized as an indispensable driver of economic development in many emerging market and low-income countries. According to the McKinsey Global Institute, from 2016 through 2030, the world needs to invest about 3.8 percent of GDP—or

\footnotetext{
${ }^{11}$ Data on income inequality are taken from the Standardized World Income Inequality Database (SWIID 5.1)
} 
an average of $\$ 3.3$ trillion a year-in economic infrastructure just to support expected rates of growth. Developing economies account for some 60 percent of that need.

Understanding therefore the effect of public investment on output is of paramount importance for policy makers in developing economies. However, empirically identifying the effect of public investment is challenging, as it would require to isolate changes in public spending that plausibly are uncorrelated with contemporaneous economic shocks.

In this paper, we follow the pioneer work of Auerbach and Gorodnichenko (2012a, $2012 b, 2013)$ to identify unanticipated shocks in public investment orthogonal to economic condition and to trace the response of output to these shocks.

The results suggest that public investment increases output in developing economies both in the short and medium term. In particular, our estimates suggest an average short-term fiscal multiplier of about 0.2 for developing economies, broadly in line with previous estimates found in the literature (e.g. Kraay 2012; Ilzetzki and others 2013). We also find that public investment shocks increase employment in the short term (with a 10 percent public investment shock increasing employment by about 0.15 percent), and tend to crowd-in private investment. In addition, we also find that the fiscal multipliers associated with public investment are larger than those for government consumption, both in the short and in the medium run.

These average effects, however, mask difference between episodes and countries. In particular, we find tentative evidence suggesting that the effects are larger: (i) during periods of slack; (ii) in economies operating with fixed exchange rate regimes; (iii) in more closed economies; (iv) in countries with lower debt; and (v) in countries with higher investment efficiency. 
Finally, we find that increases in public investment not only tend to boost output but also to lower inequality — proxied by the Gini coefficient of market income — over the medium term. An interesting avenue for further research is to examine the channels through which increased public investment affects income distribution.

These results have several policy implications. First, public investment in developing economies has the potential to increase the level of output both in the short and medium term. In order to magnify these effects, countries should improve their investment efficiency and have better initial fiscal positions. Second, the fact that public investment delivers larger medium-term output effects than government consumption suggests that shifting the composition of government expenditure away from consumption and toward public investment could be output-enhancing-symmetrically, it also suggests that fiscal consolidations based on public investment cuts could be particularly painful. Third, public investment does not seem to pose equity-efficiency tradeoffs, but instead tends to improve both macroeconomic and distributional outcomes. 


\section{REFERENCES}

Abiad, A., D. Furceri and P. Topalova. "The Macroeconomic Effects of Public Investment: Evidence from Advanced Economies.” Journal of Macroeconomics, 50, pages 224$240,2016$.

Adam, C., and D. Bevan. "Aid and the Supply Side: Public Investment, Export Performance, and Dutch Disease in Low-Income Countries." The World Bank Economic Review, vol. 20, no. 2, Apr. 2006, pp. 261-290.

Auerbach, Alan J, and Yuriy Gorodnichenko. "Measuring the Output Responses to Fiscal Policy." American Economic Journal: Economic Policy, vol. 4, no. 2, pp. 1-27, 2012a.

Auerbach, Alan J, and Yuriy Gorodnichenko. "Measuring the Output Responses to Fiscal Policy." "Fiscal Multipliers in Recession and Expansion," NBER Chapters,in: Fiscal Policy after the Financial Crisis, pages 63-98 National Bureau of Economic Research, Inc. $2012 b$.

Auerbach, Alan J, and Yuriy Gorodnichenko. "Output Spillovers from Fiscal Policy," American Economic Review, vol. 103(3), pages 141-146, 2013.

Barro, Robert. “Government Spending in a Simple Model of Endogenous Growth.” Journal of Political Economy, vol. 95, 1990, pp. 103-126.

Barro, Robert., and Xavier Sala-I-Martin. "Public Finance in Models of Economic Growth." The Review of Economic Studies, vol. 59, no. 4, 1992, pp. 645-661.

Berg, A. Buffie, E. Pattillo, C., Portillo, R. Presbitero, A. and L. Zanna, 2015. "Some Misconceptions about Public Investment Efficiency and Growth," IMF Working Papers 15/272, International Monetary Fund.

Blanchard, O., and R. Perotti. "An Empirical Characterization of the Dynamic Effects of Changes in Government Spending and Taxes on Output.” The Quarterly Journal of Economics, vol. 117, no. 4, Jan. 2002, pp. 1329-1368.

Blanchard, Olivier, and Daniel Leigh. "Growth Forecast Errors and Fiscal Multipliers." American Economic Review, vol. 103, no. 3, 2013, pp. 117-120.

Bom, Pedro R., and Jenny E. Ligthart. "What Have We Learned From Three Decades Of Research On The Productivity Of Public Capital?” Journal of Economic Surveys, vol. 28, no. 5, 2014, pp. 889-916. 
Calderón, César, and Luis Servén. "The Effects of Infrastructure Development on Growth and Income Distribution." World Bank Policy Research Working Papers, 2004.

Calderon, César, and L. Serven. "Infrastructure and Economic Development in Sub-Saharan Africa.” Journal of African Economies, vol. 19, no. 1, 2010, pp. 13-87.

Chatterjee, Santanu, and Stephen J. Turnovsky. "Foreign Aid and Economic Growth: The Role of Flexible Labor Supply.” Journal of Development Economics, vol. 84, no. 1, 2007, pp. 507-533.

Giancarlo Corsetti, André Meier and Gernot J. Müller, 2012. "What determines government spending multipliers?," Economic Policy, vol. 27(72), pages 521-565, October.

Eden, Maya, and Aart Kraay. "“Crowding in' and the Returns to Government Investment in Low-Income Countries.” Policy Research Working Papers, 2014.

Favero, Carlo, and Francesco Giavazzi. "How Large Are the Effects of Tax Changes?" NBER Working Paper, 2009.

Forni, Mario, and Luca Gambetti. "Fiscal Foresight and the Effects of Government Spending.” CEPR Discussion Paper, 2010.

Futagami, Koichi et al. "Dynamic Analysis of an Endogenous Growth Model with Public Capital." The Scandinavian Journal of Economics, vol. 95, no. 4, 1993, pp. 607-625.

Glomm, Gerhard, and B. Ravikumar. "Public Investment in Infrastructure in a Simple Growth Model." Journal of Economic Dynamics and Control, vol. 18, no. 6, 1994, pp. 1173-1187.

Granger, C. W. J., and Teräsvirta Timo. Modelling Nonlinear Economic Relationships. Oxford, Oxford University Press, 1993.

Huidrom, R, M A Kose, J J Lim, and F L Ohnsorge (2016b), "Do fiscal multipliers depend on fiscal positions?", Policy Research Working Paper Series 7734, The World Bank.

Ilzetzki, E., Mendoza E. G., and Végh C. A. "How Big (Small?) are Fiscal Multipliers?" Journal of Monetary Economics, 60:2, 2013 pp. 239-254.

Jordà, Òscar. "Estimation and Inference of Impulse Responses by Local Projections." American Economic Review, vol. 95, no. 1, 2005, pp. 161-182.

Kraay, A. "How Large Is the Government Spending Multiplier? Evidence from World Bank Lending.” The Quarterly Journal of Economics, vol. 127, no. 2, 2012, pp. 829-887. 
Kraay, Aart. "Government Spending Multipliers in Developing Countries: Evidence from Lending by Official Creditors." American Economic Journal: Macroeconomics, vol. 6, no. 4, 2014, pp. 170-208.

Leeper, Eric M et al. "Corrigendum: Quantitative Effects of Fiscal Foresight." American Economic Journal: Economic Policy, vol. 4, no. 3, 2012, pp. 283-283.

Leeper, Eric M. et al. "Fiscal Foresight and Information Flows." Econometrica, vol. 81, no. 3, 2013, pp. 1115-1145.

Portillo, Rafael et al. "The Macroeconomics of Medium-Term Aid Scaling-Up Scenarios." IMF Working Papers, vol. 10, no. 160, 2010.

Portillo, Rafael et al. "Public Investment, Growth, and Debt Sustainability: Putting Together the Pieces." IMF Working Papers, vol. 12, no. 144, 2012.

Romer, Christina D, and David H Romer. "The Macroeconomic Effects of Tax Changes: Estimates Based on a New Measure of Fiscal Shocks.” American Economic Review, vol. 100 , no. 3 , 2010, pp. 763-801.

Romp, Ward, and Jakob De Haan. "Public Capital and Economic Growth: A Critical Survey." Perspektiven Der Wirtschaftspolitik, vol. 8, no. S1, 2007, pp. 6-52.

Stock, James H., and Mark W. Watson. "Why Has U.S. Inflation Become Harder to Forecast?" Journal of Money, Credit and Banking, vol. 39, 2007, pp. 3-33.

Zeev, Nadav Ben, and Evi Pappa. "Chronicle of a War Foretold: The Macroeconomic Effects of Anticipated Defense Spending Shocks.” The Economic Journal, 2015. 
Figure 1. The effect of public investment shocks on output (percent)

0.7

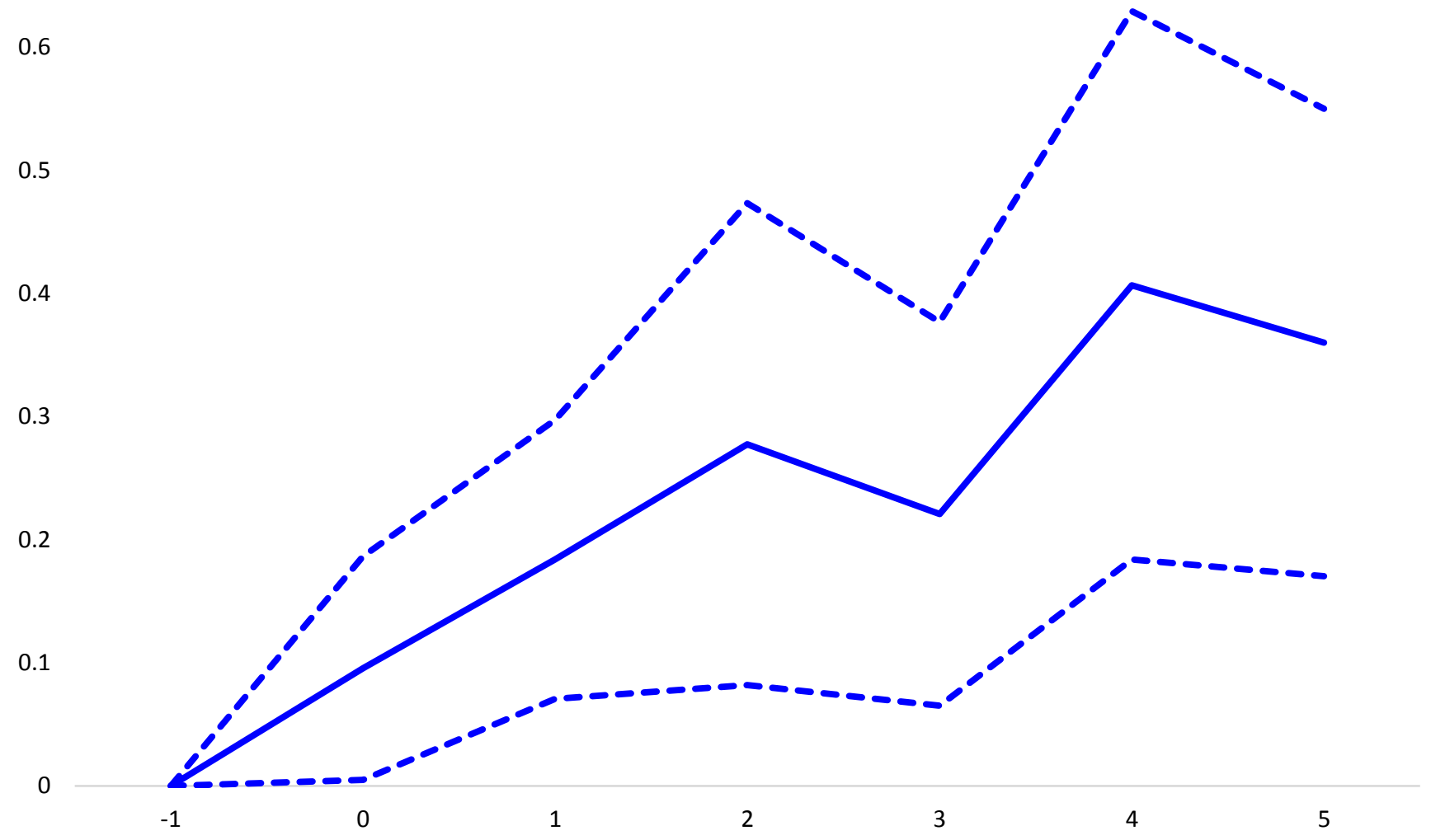

Note: $\mathrm{t}=0$ is the year of the shock. Solid blue lines denote the response to an unanticipated 10 percent increase in public investment, and dashed lines denote 90 percent confidence bands. Estimates based on equation (2). 
Figure 2. The effect of public investment shocks on employment (percent)

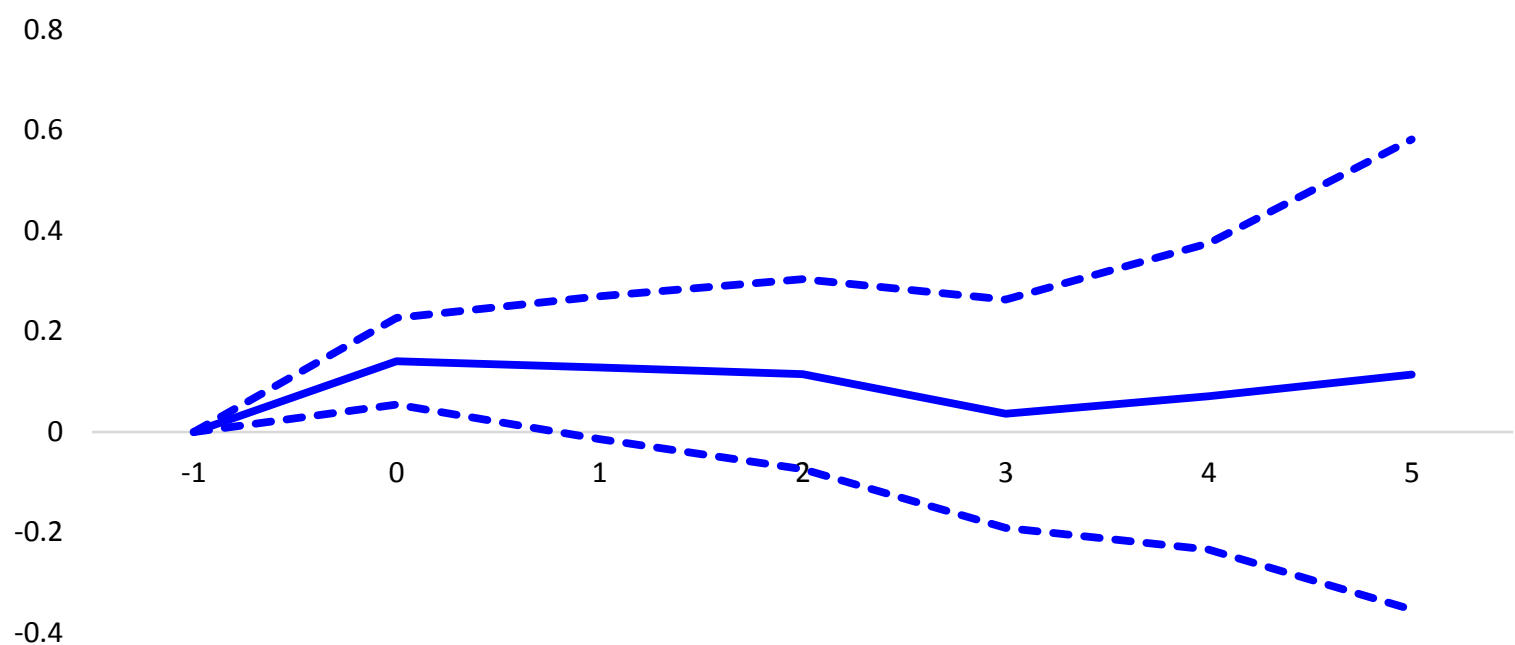

Note: $\mathrm{t}=0$ is the year of the shock. Solid blue lines denote the response to an unanticipated 10 percent increase in public investment, and dashed lines denote 90 percent confidence bands. Estimates based on equation (2).

Figure 3. The effect of public investment shocks on private investment (percent)

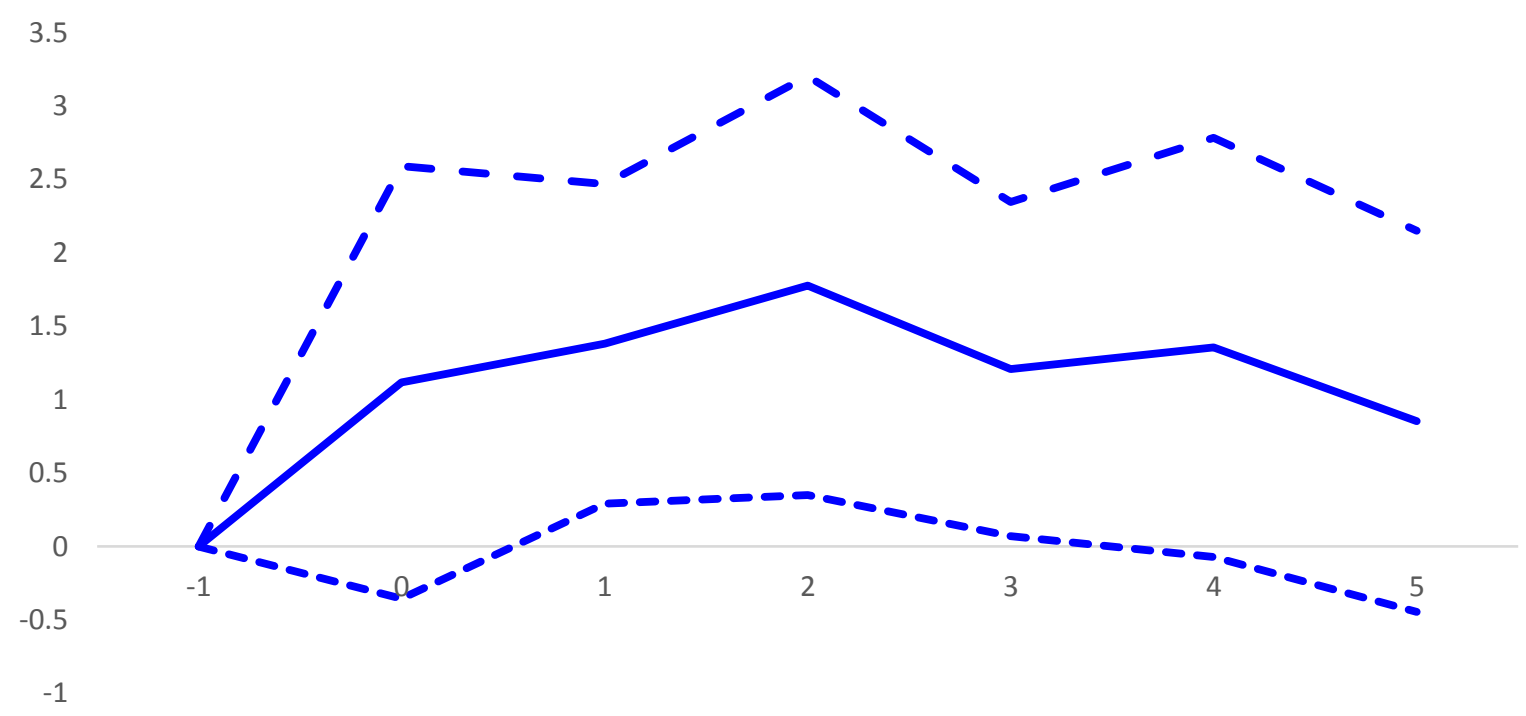

Note: $t=0$ is the year of the shock. Solid blue lines denote the response to an unanticipated 10 percent increase in public investment, and dashed lines denote 90 percent confidence bands. Estimates based on equation (2). 
Figure 4. The output effect of public investment shocks (percent) - Robustness checks I

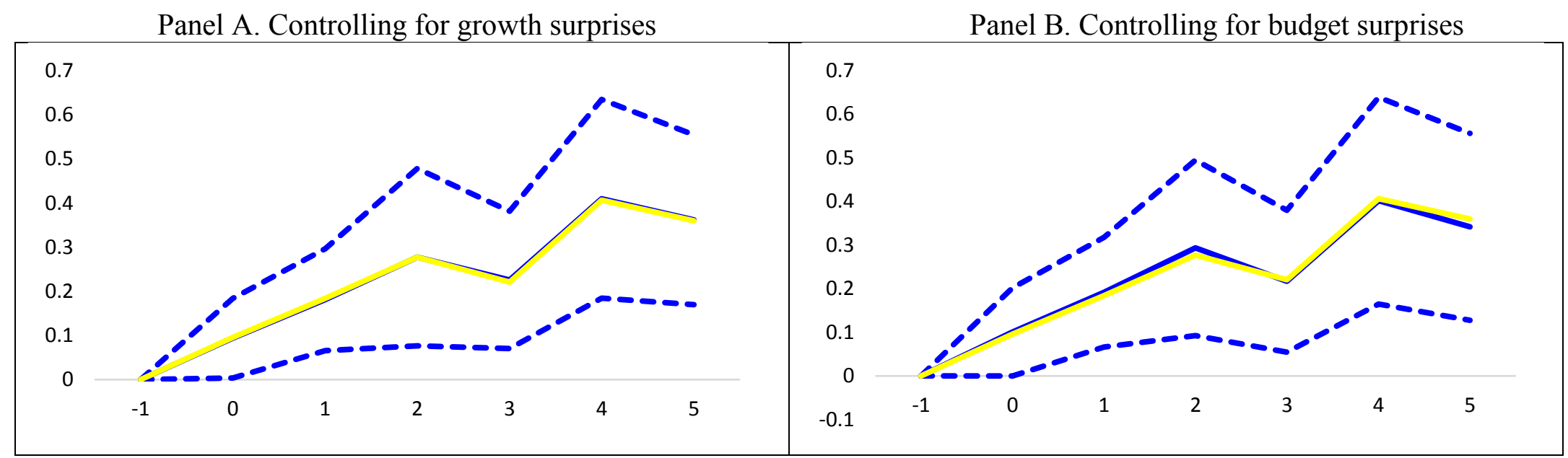

Panel C. Using previous year forecast

Panel D. Post 2005

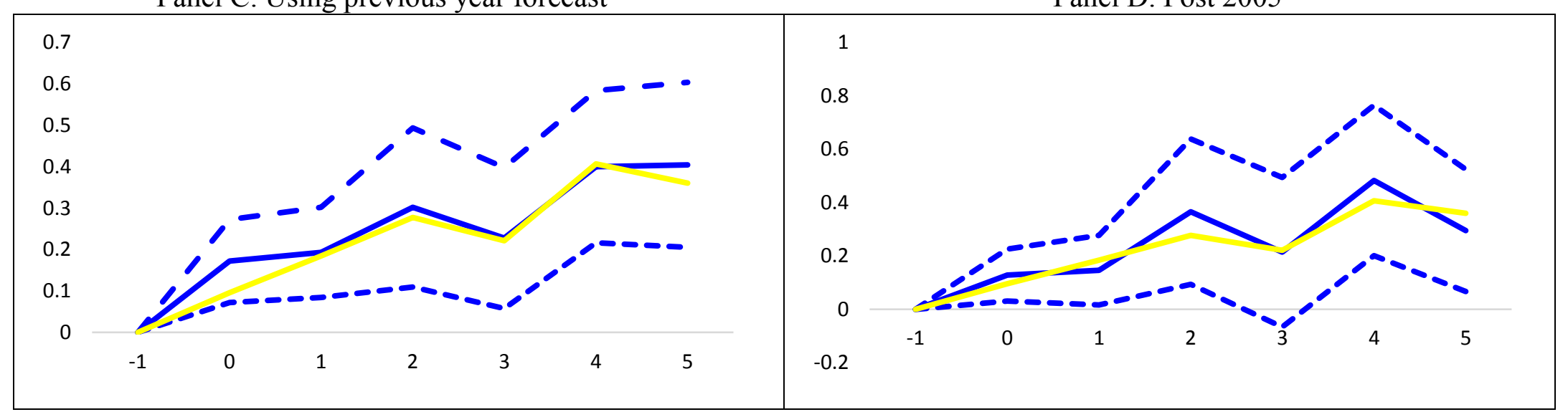

Note: $\mathrm{t}=0$ is the year of the shock. Solid blue lines denote the response to an unanticipated 10 percent increase in public investment, and dashed lines denote 90 percent confidence bands. Estimates based on equation (2). Yellow lines are the baseline effects reported in Figure 1. 
Figure 5. The output effect of public investment shocks (percent) - Emerging markets vs. low-income countries

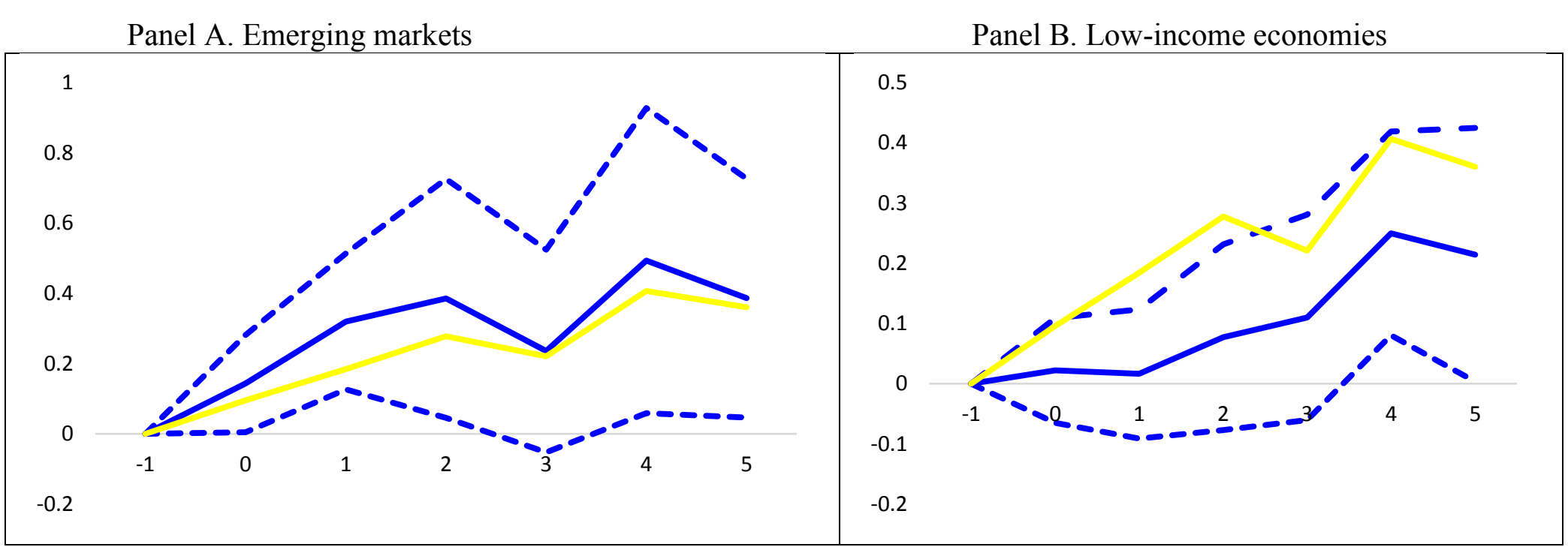

Note: $\mathrm{t}=0$ is the year of the shock. Solid blue lines denote the response to an unanticipated 10 percent increase in public investment, and dashed lines denote 90 percent confidence bands. Estimates based on equation (2). Yellow lines are the baseline effects reported in Figure 1. The classification of emerging markets and low-income countries follows the one of the IMD World Economic Outlook. 
Figure 6. The output effect of public investment shocks (percent)— controlling for influential observations

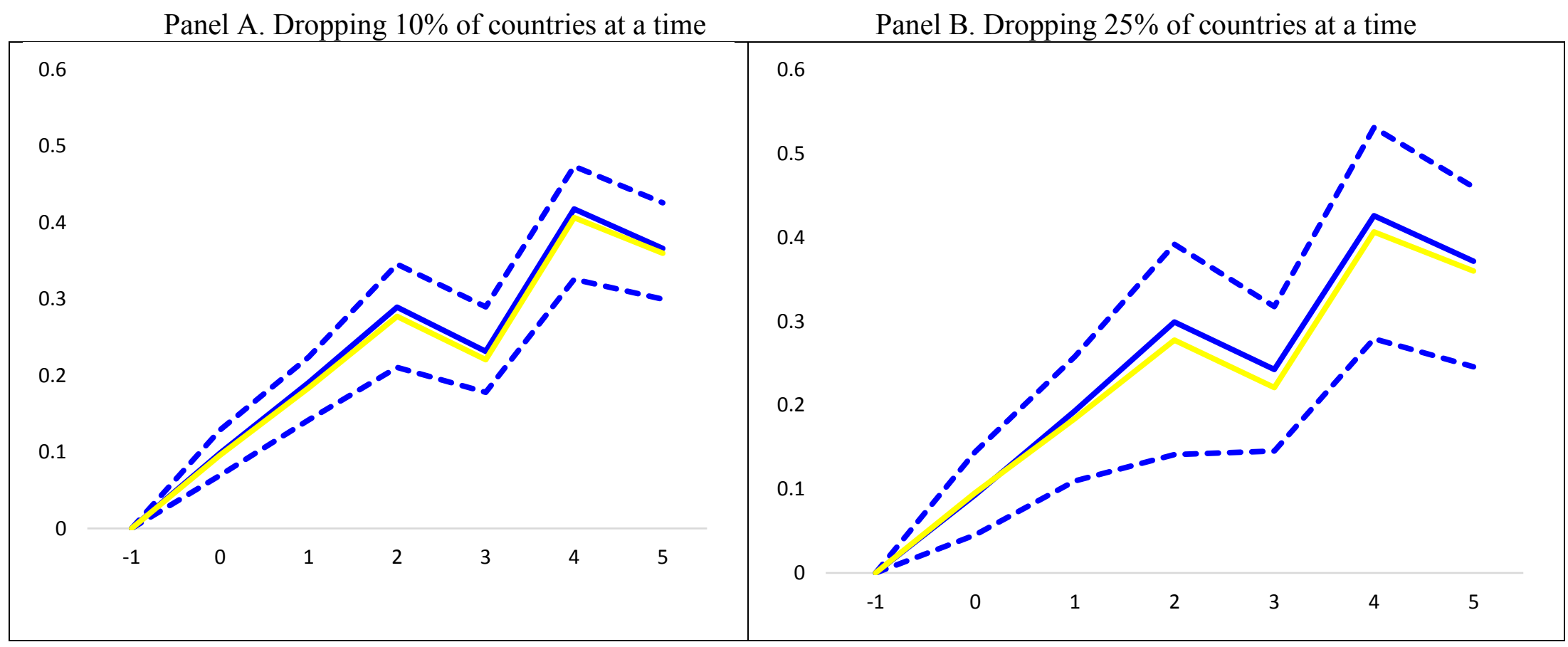

Note: $\mathrm{t}=0$ is the year of the shock. Solid blue lines denote the average response to an unanticipated 10 percent increase in public investment from 100 replications, and dashed lines denote the associated 90 percent confidence bands. Estimates based on equation (2). Yellow lines are the baseline effects reported in Figure 1. 
Figure 7. The output effect of public investment shocks (percent)— the role of business cycle

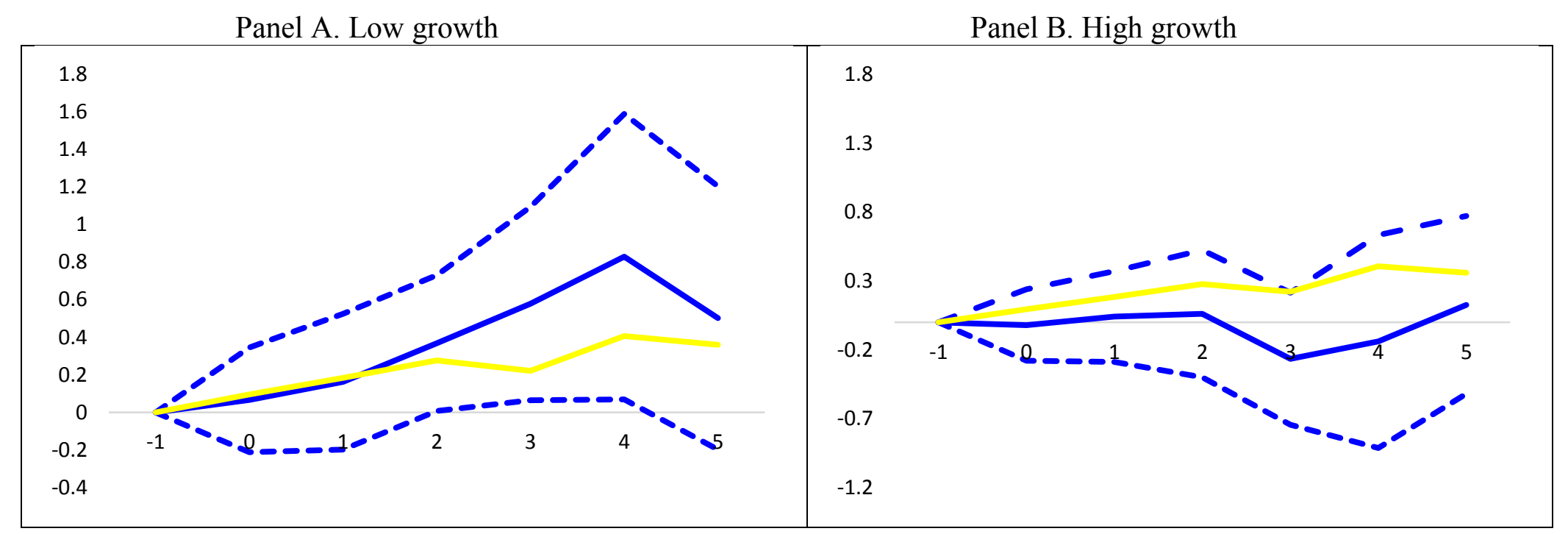

Note: $t=0$ is the year of the shock. Solid blue lines denote the response to an unanticipated 10 percent increase in public investment, and dashed lines denote 90 percent confidence bands. Estimates based on equation (3). Effects under strong (weak) business cycle conditions are shown here using $\mathrm{G}=0$ ( $\mathrm{G}=1)$. Yellow lines are the baseline effects reported in Figure 1. 
Figure 8. The output effect of public investment shocks (percent) — the role of exchange rate regimes

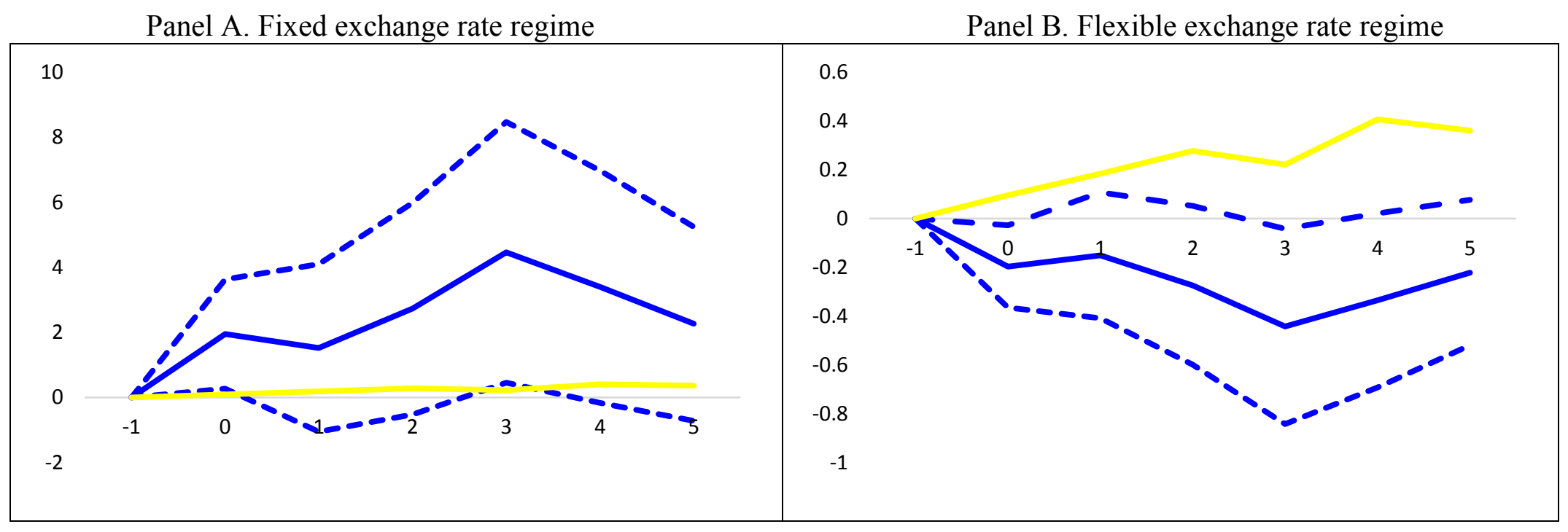

Note: $t=0$ is the year of the shock. Solid blue lines denote the response to an unanticipated 10 percent increase in public investment, and dashed lines denote 90 percent confidence bands. Estimates based on equation (3). Effects under fixed (flexible) exchange rate regimes are shown here using $G=0$ ( $G=1$ ). Yellow lines are the baseline effects reported in Figure 1. 
Figure 9. The output effect of public investment shocks (percent)— the role of trade openness

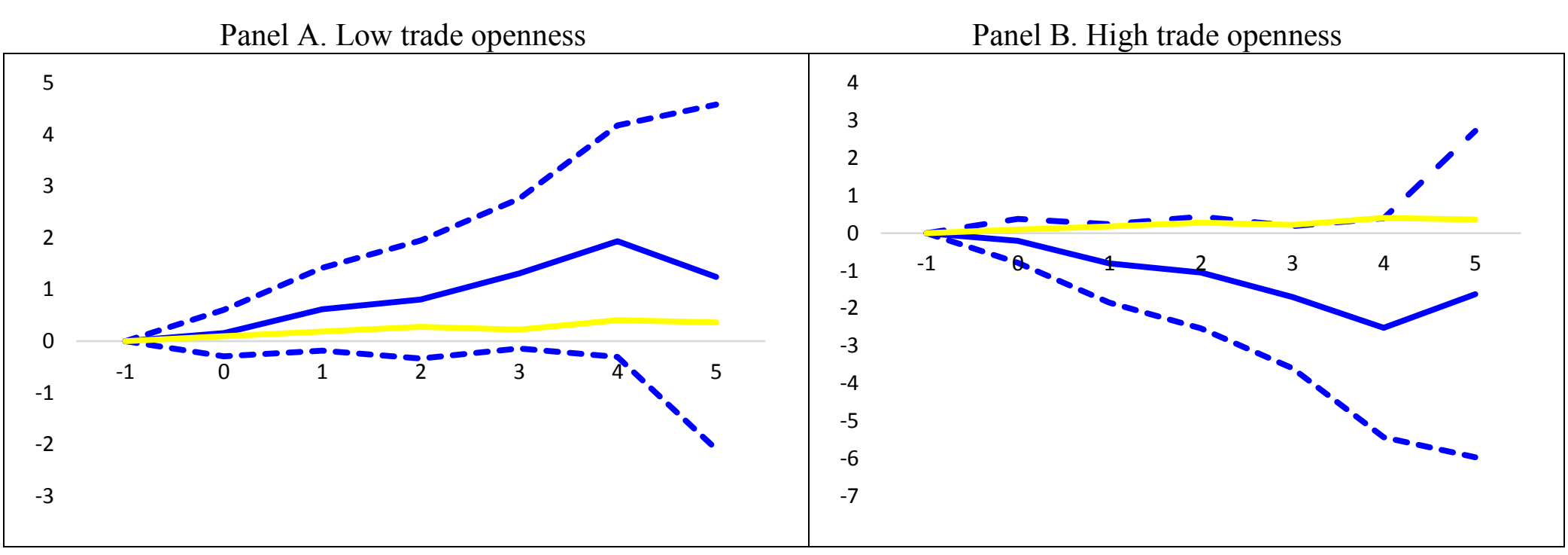

Note: $\mathrm{t}=0$ is the year of the shock. Solid blue lines denote the response to an unanticipated 10 percent increase in public investment, and dashed lines denote 90 percent confidence bands. Estimates based on equation (3). Effects under low (high) trade openess are shown here using $G=0(\mathrm{G}=1)$. Yellow lines are the baseline effects reported in Figure 1. 


\section{Figure 10. The output effect of public investment shocks (percent)— the role of public debt}

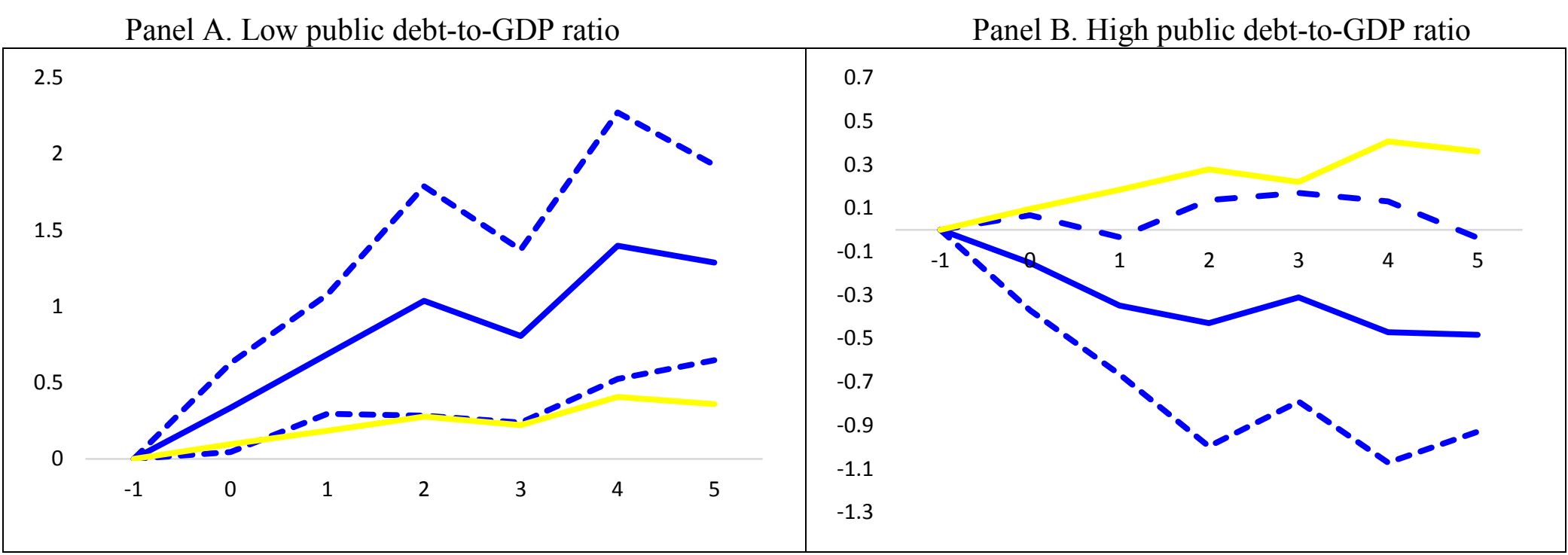

Note: $\mathrm{t}=0$ is the year of the shock. Solid blue lines denote the response to an unanticipated 10 percent increase in public investment, and dashed lines denote 90 percent confidence bands. Estimates based on equation (3). Effects under low (weak) public debt are shown here using $\mathrm{G}=0$ ( $\mathrm{G}=1$ ). Yellow lines are the baseline effects reported in Figure 1. 
Figure 11. The output effect of public investment shocks (percent) — the role of investment efficiency

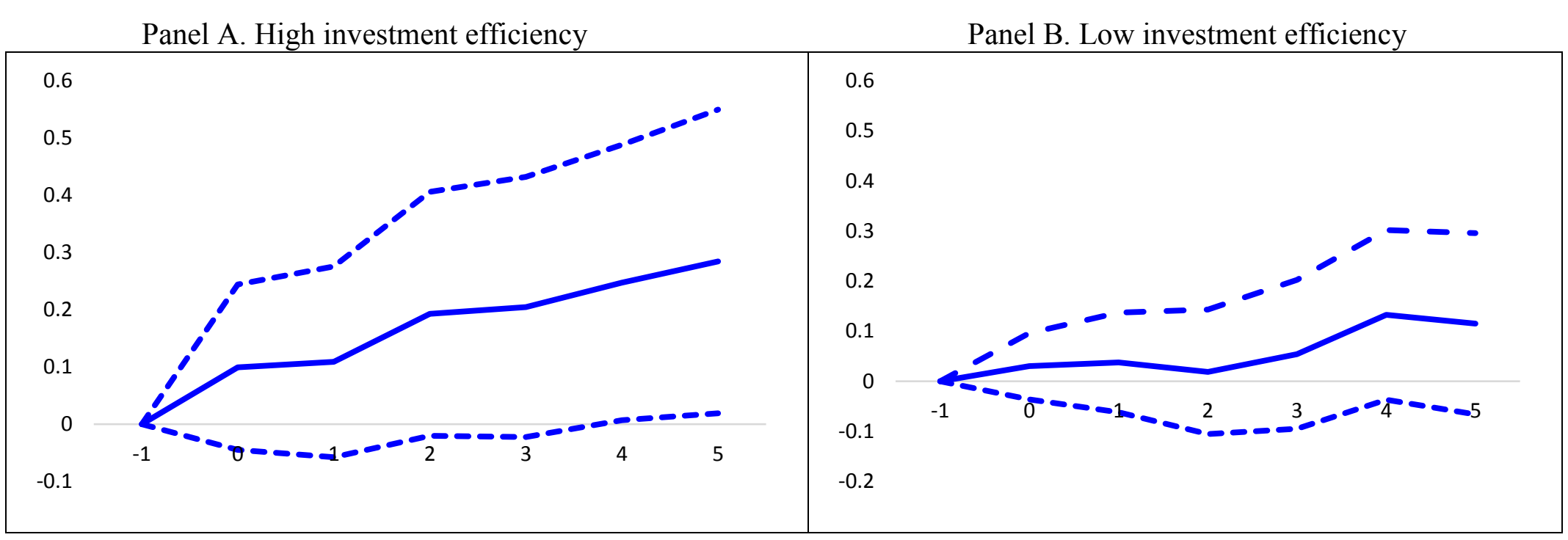

Note: $\mathrm{t}=0$ is the year of the shock. Solid blue lines denote the response to an unanticipated 10 percent increase in public investment, and dashed lines denote 90 percent confidence bands. Estimates based on equation (3). Effects under strong (weak) investment efficiency are shown here using $\mathrm{G}=0(\mathrm{G}=1)$. 
Figure 12. The effect of public consumption shocks on output (percent)

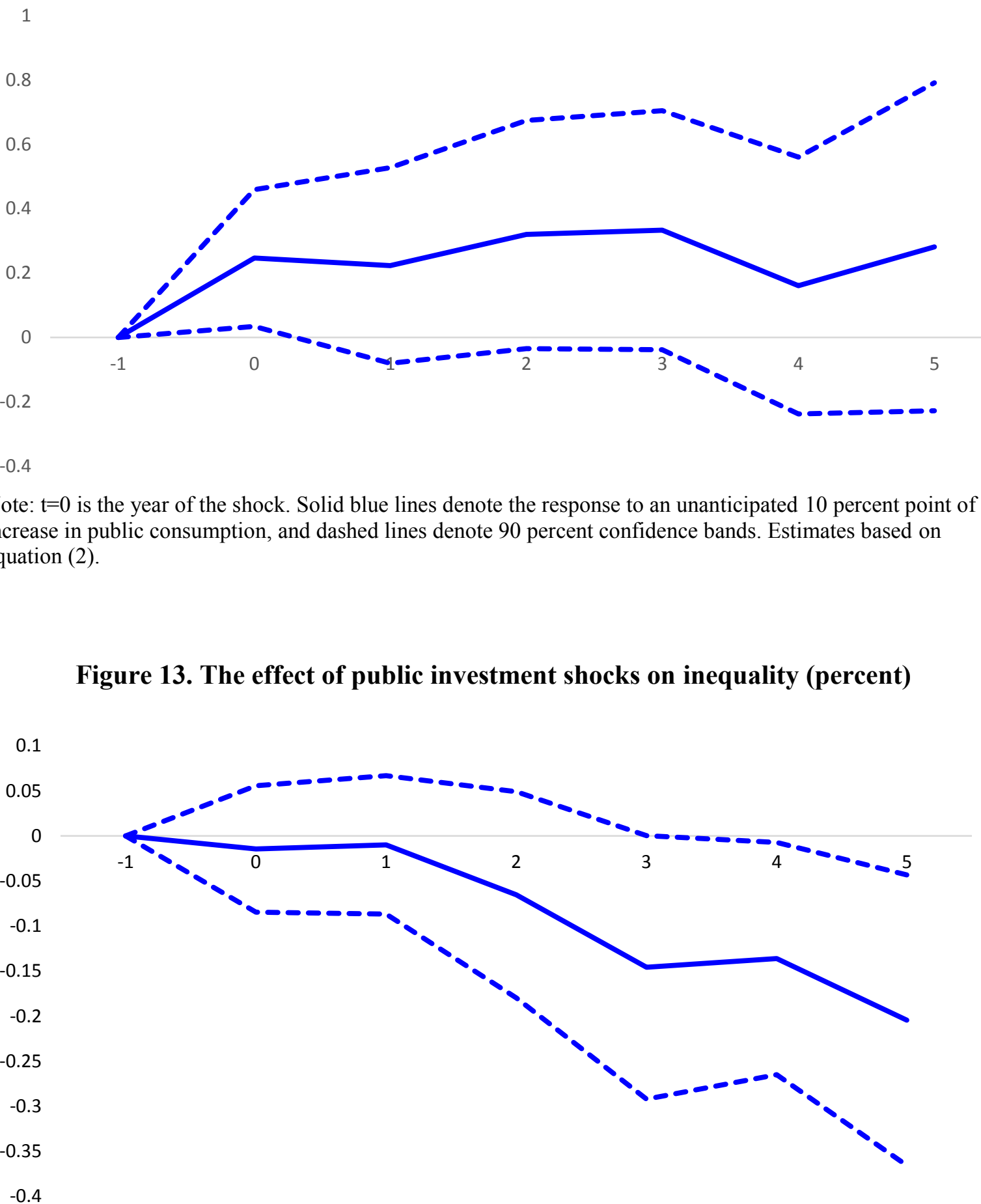

Note: $t=0$ is the year of the shock. Solid blue lines denote the response to an unanticipated 10 percent point of increase in public investment, and dashed lines denote 90 percent confidence bands. Estimates based on equation (2). 
Table 1. The effect of public investment shocks on output

\begin{tabular}{|c|c|c|c|c|c|c|}
\hline & $\mathrm{K}=\mathbf{0}$ & $K=1$ & $K=2$ & $\mathbf{K}=\mathbf{3}$ & $K=4$ & $K=5$ \\
\hline \multirow[t]{2}{*}{ growth(t-1) } & $0.139 * * *$ & $0.148 * *$ & $0.139 * * *$ & 0.094 & -0.006 & $-0.346 * * *$ \\
\hline & $(3.13)$ & $(2.59)$ & $(3.13)$ & $(0.96)$ & $(0.96)$ & $(-2.63)$ \\
\hline \multirow[t]{2}{*}{$\operatorname{growth}(\mathrm{t}-2)$} & -0.002 & 0.056 & -0.002 & -0.080 & -0.215 & -0.134 \\
\hline & $(-0.06)$ & $(0.47)$ & $(-0.06)$ & $(-0.49)$ & $(-0.93)$ & $(-0.48)$ \\
\hline \multirow[t]{2}{*}{ Public investment shock (t) } & $0.010 *$ & $0.018 * * *$ & $0.028 * *$ & $0.022 * *$ & $0.041 * * *$ & $0.010 *$ \\
\hline & $(1.73)$ & $(2.67)$ & $(2.33)$ & $(2.33)$ & $(3.00)$ & $(1.73)$ \\
\hline \multirow[t]{2}{*}{ Public investment shock (t-1) } & 0.001 & -0.000 & 0.000 & 0.000 & 0.000 & $0.010 *$ \\
\hline & (1.07) & $(-0.07)$ & $(0.35)$ & $(0.48)$ & $(0.55)$ & $(1.65)$ \\
\hline \multirow[t]{2}{*}{ Public investment shock ( $\mathrm{t}-2)$} & -0.001 & -0.001 & -0.000 & -0.000 & 0.001 & -0.000 \\
\hline & $(-1.13)$ & $(-0.60)$ & $(-0.03)$ & $(-0.32)$ & $(0.95)$ & $(-0.37)$ \\
\hline $\mathrm{N}$ & 1022 & 1021 & 943 & 866 & 791 & 715 \\
\hline $\mathrm{R}^{2}$ & 0.33 & 0.37 & 0.48 & 0.56 & 0.64 & 0.70 \\
\hline
\end{tabular}

Note: T-statistics based on robust clustered standard errors in parenthesis. $* * * * * * *$ denote significance at 1 percent, 5 percent and 10 percent, respectively. Estimates based on equation (3). 
Figure A1. Public investment shocks (percent)

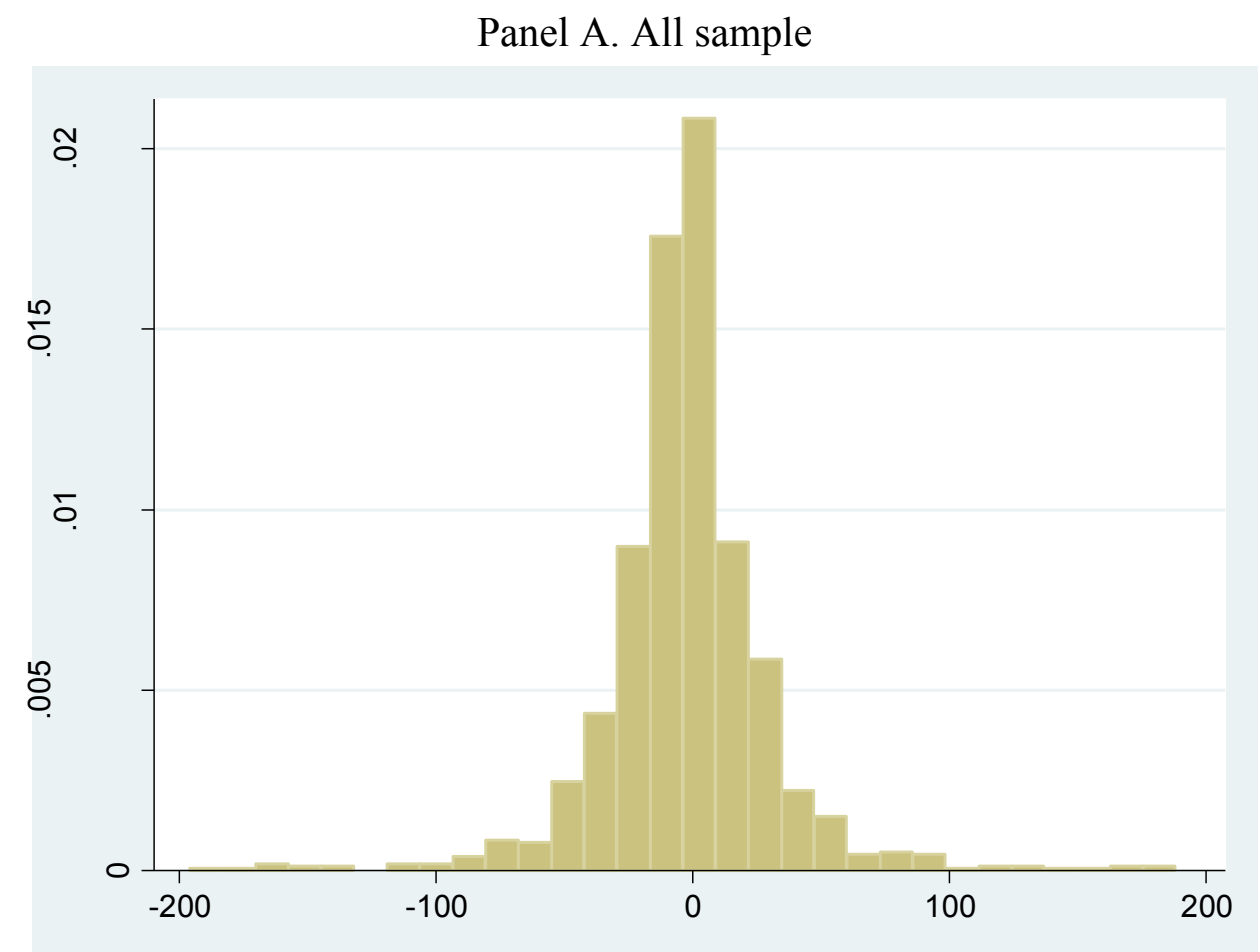

Panel B. Emerging markets

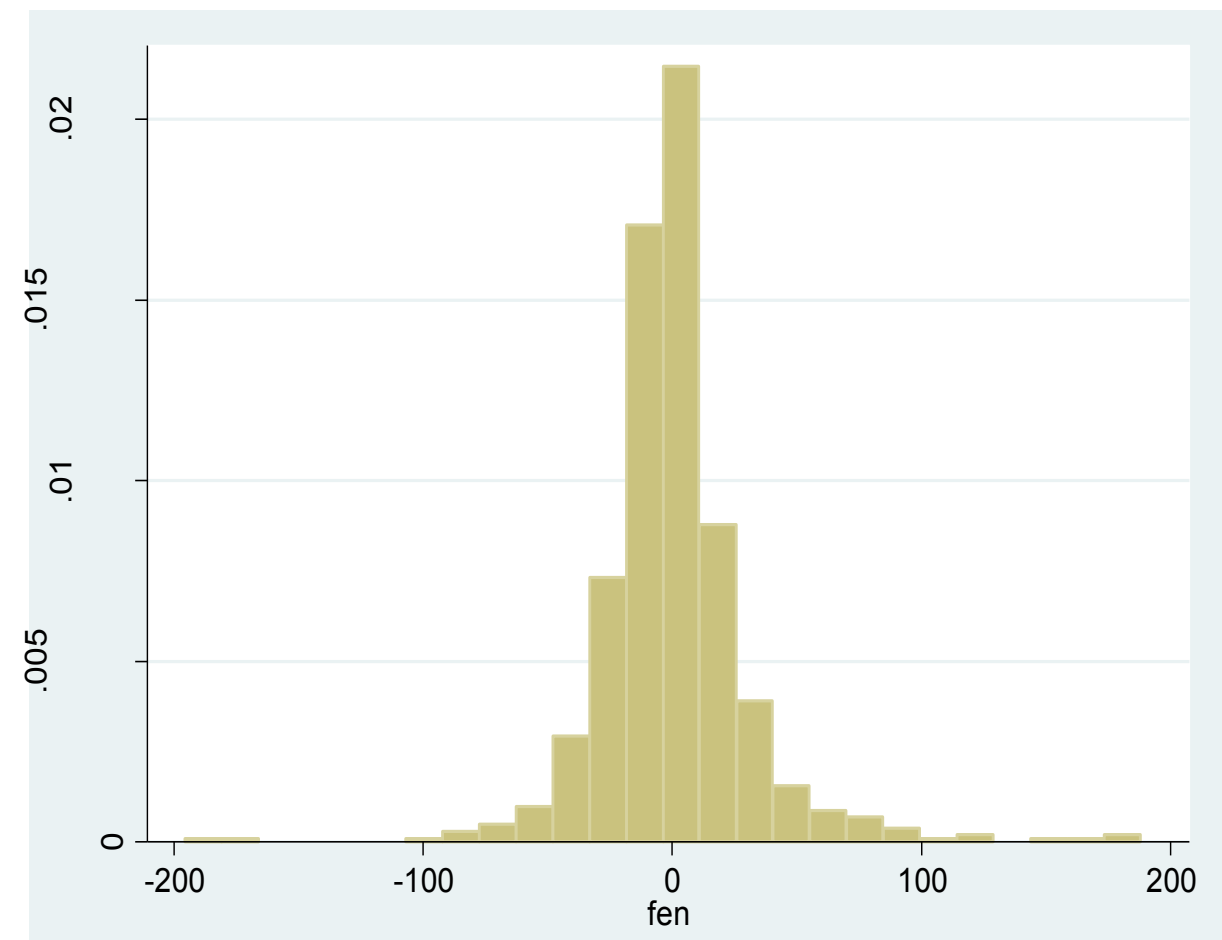




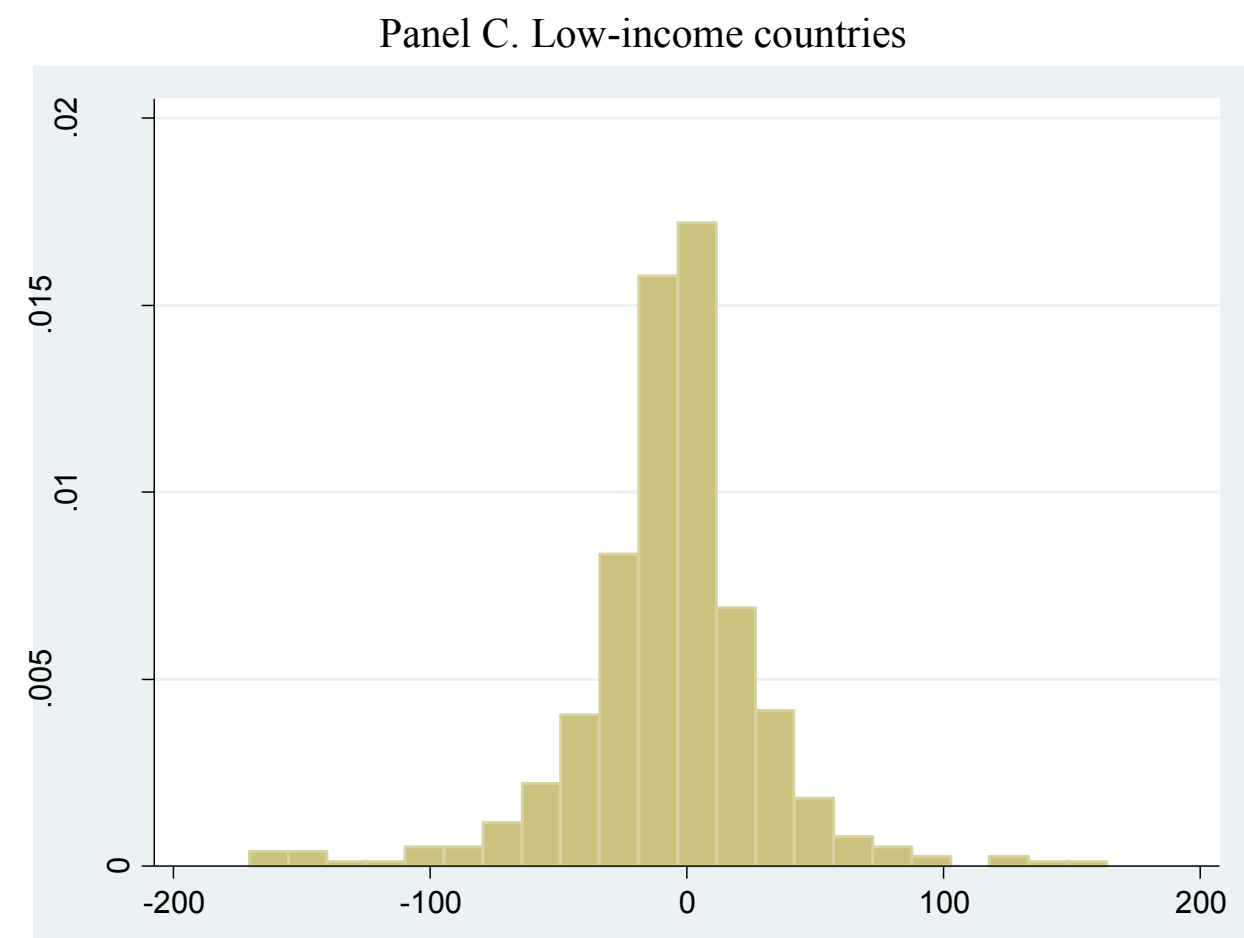

Note: the classification of emerging market economies and developing economies is the one of IMF WEO. 
Table A1. List of countries in the sample

\begin{tabular}{|c|c|c|c|c|c|}
\hline Country & Emerging markets & Low-income & Country & Emerging markets & Low-income \\
\hline Afghanistan & 0 & 1 & Lesotho & 0 & 1 \\
\hline Algeria & 1 & 0 & Libya & 1 & 0 \\
\hline Angola & 1 & 0 & Madagascar & 0 & 1 \\
\hline Armenia & 1 & 0 & Malawi & 0 & 1 \\
\hline Bahrain & 1 & 0 & Mali & 0 & 1 \\
\hline Bangladesh & 0 & 1 & Mauritania & 0 & 1 \\
\hline Barbados & 1 & 0 & Mauritius & 1 & 0 \\
\hline Benin & 0 & 1 & Mexico & 1 & 0 \\
\hline Bosnia Herzegovina & 1 & 0 & Moldova & 0 & 1 \\
\hline Botswana & 1 & 0 & Morocco & 1 & 0 \\
\hline Brazil & 1 & 0 & Mozambique & 0 & 1 \\
\hline Burkina Faso & 0 & 1 & Namibia & 1 & 0 \\
\hline Cameroon & 0 & 1 & Nicaragua & 0 & 1 \\
\hline Capo Verde & 1 & 0 & Nigeria & 0 & 1 \\
\hline Central African Rep. & 0 & 1 & Oman & 1 & 0 \\
\hline Chad & 0 & 1 & Pakistan & 1 & 0 \\
\hline China & 1 & 0 & Peru & 1 & 0 \\
\hline Comoros & 0 & 1 & Qatar & 1 & 0 \\
\hline Congo, Republic of & 0 & 1 & Romania & 1 & 0 \\
\hline Costa Rica & 1 & 0 & Rwanda & 0 & 1 \\
\hline Cote d'Ivoire & 0 & 1 & Sao Tome \& Pr. & 0 & 1 \\
\hline Djibouti & 0 & 1 & Saudi Arabia & 1 & 0 \\
\hline Dominican Republic & 1 & 0 & Senegal & 0 & 1 \\
\hline Egypt & 1 & 0 & Serbia & 1 & 0 \\
\hline El Salvador & 1 & 0 & Seychelles & 1 & 0 \\
\hline Equatorial Guinea & 1 & 0 & Sierra Leone & 0 & 1 \\
\hline Eritrea & 0 & 1 & South Africa & 1 & 0 \\
\hline Ethiopia & 0 & 1 & Swaziland & 1 & 0 \\
\hline Gabon & 1 & 0 & Tanzania & 0 & 1 \\
\hline Gambia, the & 0 & 1 & Thailand & 1 & 0 \\
\hline Ghana & 0 & 1 & Togo & 0 & 1 \\
\hline Guatemala & 1 & 0 & Turkey & 1 & 0 \\
\hline Guinea & 0 & 1 & Uganda & 0 & 1 \\
\hline Guinea-Bissau & 0 & 1 & United Arab Em. & 1 & 0 \\
\hline Haiti & 0 & 1 & Uruguay & 1 & 0 \\
\hline Honduras & 0 & 1 & Venezuela & 1 & 0 \\
\hline Iran & 1 & 0 & Yemen & 0 & 1 \\
\hline Jordan & 1 & 0 & Zambia & 0 & 1 \\
\hline Kuwait & 1 & 0 & Zimbabwe & 0 & 1 \\
\hline Lebanon & 1 & 0 & & & \\
\hline
\end{tabular}


Table A2. List of countries and the sample periods

\begin{tabular}{|c|c|c|c|}
\hline Country & Coverage & Country & Coverage \\
\hline Afghanistan & $2005-2013$ & Lesotho & $2001-2013$ \\
\hline Algeria & $1995-2013$ & Libya & $2000-2013$ \\
\hline Angola & $2006-2013$ & Madagascar & 2001-2013 \\
\hline Armenia & $2002-2013$ & Malawi & $2006-2013$ \\
\hline Bahrain & $1996-2013$ & Mali & 2001-2013 \\
\hline Bangladesh & $1990-2013$ & Mauritania & 1999-2013 \\
\hline Barbados & $1995-2013$ & Mauritius & 2001-2013 \\
\hline Benin & 2001-2013 & Mexico & $1990-2013$ \\
\hline Bosnia Herzegovina & 2003-2013 & Moldova & $1998-2013$ \\
\hline Botswana & 2001-2013 & Morocco & 1999-2013 \\
\hline Brazil & $1991-2013$ & Mozambique & $2001-2013$ \\
\hline Burkina Faso & 2001-2013 & Namibia & $2001-2013$ \\
\hline Cameroon & $2001-2013$ & Nicaragua & $2002-2013$ \\
\hline Capo Verde & $2003-2013$ & Nigeria & $2000-2013$ \\
\hline Central African Rep. & 2001-2013 & Oman & $1993-2013$ \\
\hline Chad & $2006-2013$ & Pakistan & $1992-2013$ \\
\hline China & $2003-2013$ & Peru & $1991-2013$ \\
\hline Comoros & 2001-2013 & Qatar & $2000-2013$ \\
\hline Congo, Republic of & 2001-2013 & Romania & $2001-2013$ \\
\hline Costa Rica & 2001-2013 & Rwanda & $2001-2013$ \\
\hline Cote d'Ivoire & $2001-2013$ & Sao Tome \& Pr. & $2002-2013$ \\
\hline Djibouti & $1996-2013$ & Saudi Arabia & $1995-2013$ \\
\hline Dominican Republic & $1998-2013$ & Senegal & 2001-2013 \\
\hline Egypt & $1991-2013$ & Serbia & $2007-2013$ \\
\hline El Salvador & $1992-2013$ & Seychelles & $2007-2013$ \\
\hline Equatorial Guinea & $2001-2013$ & Sierra Leone & $2004-2013$ \\
\hline Eritrea & $2001-2013$ & South Africa & $2001-2013$ \\
\hline Ethiopia & $2001-2013$ & Swaziland & $2001-2013$ \\
\hline Gabon & $1992-2013$ & Tanzania & $2006-2013$ \\
\hline Gambia, the & $2001-2013$ & Thailand & $1991-2013$ \\
\hline Ghana & $1991-2013$ & Togo & $2001-2013$ \\
\hline Guatemala & $2002-2013$ & Turkey & $1990-2013$ \\
\hline Guinea & $1997-2013$ & Uganda & $2001-2013$ \\
\hline Guinea-Bissau & $2004-2013$ & United Arab Em. & $1994-2013$ \\
\hline Haiti & $1996-2013$ & Uruguay & $1998-2013$ \\
\hline Honduras & $2001-2013$ & Venezuela & $1998-2013$ \\
\hline Iran & $1992-2013$ & Yemen & 1999-2013 \\
\hline Jordan & $1991-2013$ & Zambia & $2001-2013$ \\
\hline Kuwait & $1992-2013$ & Zimbabwe & $2012-2013$ \\
\hline Lebanon & $1998-2013$ & & \\
\hline
\end{tabular}

